\title{
China-India Bilateral Trade:
}

Strong Fundamentals, Bright Future

\section{Swaran Singh}

\section{CpenEdition}

\section{Journals}

Édition électronique

URL : http://journals.openedition.org/chinaperspectives/2853

DOI : 10.4000/chinaperspectives.2853

ISSN : 1996-4617

Éditeur

Centre d'étude français sur la Chine contemporaine

Édition imprimée

Date de publication : 1 décembre 2005

ISSN : 2070-3449

\section{Référence électronique}

Swaran Singh, «China-India Bilateral Trade: », China Perspectives [En ligne], 62 I november - december 2005, mis en ligne le 01 décembre 2008, consulté le 28 octobre 2019. URL : http://

journals.openedition.org/chinaperspectives/2853 ; DOI : 10.4000/chinaperspectives.2853

Ce document a été généré automatiquement le 28 octobre 2019.

(C) All rights reserved 


\title{
China-India Bilateral Trade:
}

\author{
Strong Fundamentals, Bright Future
}

Swaran Singh

China and India today represent Asia's two largest and most dynamic societies which are emerging as new trend setters in international relations. Especially, with their annual GDP growth rates standing respectively at $9.1 \%$ and $8.5 \%$ for 2003 and at $9.5 \%$ and $6.9 \%$ for 2004, China and India have since come to be recognised as the fastest growing economies. According to World Bank estimates, and assessed on the basis of purchasing power parity, China and India have already become respectively the second and fourth largest economies of the world surpassing developed countries ${ }^{1}$.

2 From the global perspective, China and India today represent two unique new playerspresenting an extraordinary combination of a very large GDP and still with significant poverty and pockets of unrest and a very low per capita income and living standards. This unique combination raises several questions about their becoming major drivers in international economic trends. However, in the politico-strategic sphere, their recent economic success has resulted in both seeking an expanded space in regional as well as international decision-making, something that is becoming a matter for worldwide concern.

3 Thanks, however, to their colonial and cold war legacies, their economic success had, for a long time, remained a mutually exclusive exercise thus slowing down its pace of progress and its global impact. It is only rather recently that their political initiatives at confidence-building began to expand their areas of mutual co-operation, which now remains premised on their new mantra of mutual accommodation and mutual benefit ${ }^{2}$. Their bilateral trade has since come to be recognised as the most reliable as also the most agreeable instrument of China-India rapprochement. Their long-term potential as trade partners, however, remains yet to be fully explored and exploited and their political equations remain yet vulnerable to their problematic legacies ${ }^{3}$.

4 It is in this context of their fast changing equations that this article makes an attempt to hypothesise how their bilateral trade promises to become the most potent instrument for resolving their political difficulties and facilitate progress in actualising their strategic partnership for the future. This China-India economic partnership 
remains an essential prerequisite for the success of their regional and global political initiatives.

The new context

5 The context of China-India bilateral trade itself-bilateral as well as regional and global -has been changing rapidly. At the bilateral level, this is self-evident in the way their rapidly growing trade partnership has provided a great boost to their ongoing political confidence-building. In the wake of their diplomatic stand-off following India's nuclear tests of May 1998, their bilateral trade was the first to bounce back to its normal pace ${ }^{4}$. However, this boom in their bilateral trade could not have been possible in absence of bold political initiatives yet, in recent years, it is the role of their business communities that has become far more influential in determining the tone and tenor of their political interactions.

Their recent signing of the April 2005 "general parameters" agreement for their boundary settlement, their opening of a third border trade route through Sikkim in June 2003, and now their discussions for evolving a China-India Free Trade Area (FTA) remain some of the examples which have been accompanied by a reduction in forces deployment on their border and revival of several cottage industries among border communities in remote and inaccessible regions ${ }^{5}$. Apparently, policy-makers from both sides have begun to increasingly focus on the social and political spin-offs of their bilateral trade. The last five years have witnessed China-India trade quadruple and the expectation that it will reach US $\$ 30$ billion by 2010 appears increasingly credible 6 .

7 However, for both China and India, their rise to stardom is no without its share of pitfalls, puzzles and challenges. Much of the aforementioned success remains particularly true of China with India slightly behind. India's Prime Minister Manmohan Singh is seen as an architect of India's economic reforms and opening up ${ }^{7}$. However, even without government initiatives, several sectors in India have picked up momentum and will continue to grow helping New Delhi to catch up with Peking. For example, the number of skilled professionals from India are growing at enormous speed. They mainly work in the software industry, and Chinese enthusiasm for India's information technology sector clearly recognises this new trend ${ }^{8}$.

Trends in bilateral trade ties

8 Nothing compares to the China-India bilateral trade when it comes to evaluating the positive trends in post-1962 China-India relations. Starting with an extremely slow pace with an annual turnover of only a few million dollars, and then staying on the margins for much of the 1980s, their trade has gradually come to occupy the centre stage of their interaction. The target of reaching US $\$ 20$ billion in bilateral trade by $2008-$ set by the two prime ministers in their meeting in Delhi in April 2005-is now expected to be reached before end of 2005. Similarly, the target of US $\$ 30$ billon of bilateral trade set for 2010 is now expected to be reached by $2008^{\circ}$. At least in the short-run, their current institutional arrangements and enthusiasm augurs very well for their continued trade boom, which can contribute a great deal to their growing confidence one in the other and their evolving long-term strategic partnership ${ }^{10}$.

9 Especially, China's foreign trade stood at US $\$ 851$ billion for 2003 and exceeded US $\$ 1$ trillion for 2004. India's foreign trade, by comparison, reached only about US $\$ 180$ billion for 2004. If the East Asian financial crisis had diverted China's trade to India then the countertrends in the wake of India's nuclear tests of May 1998, resulted in India's total foreign trade sliding from US $\$ 86.86$ for 1998 to US\$81.84 billion for 1999 . 
However, this general slide was not proportionally reflected in the China-India bilateral trade though China this was perhaps one area most directly affected by India's nuclear tests (see Figure 1).

Positive trends in the bilateral trade have been particularly shaped by the economic reforms on both sides and the consequent search for new business partners. As a result of this, their complicated politico-strategic equations, that had continued to slow the rising enthusiasm, have come to be underplayed and marginalised. To cite some examples of China using trade as its diplomatic tool, its trade with other problematic neighbours like Japan and South Korea has increased respectively from US $\$ 16.8$ billon and US $\$ 0.7$ billion for 1990 to a whopping US\$99.6 billion and US\$36.2 billion for 2002, making them each other's most valued trade partners. China's combined trade with Japan and South Korea reached US $\$ 212$ billion for $2004^{11}$. For the same period, China's bilateral trade with India grew from US $\$ 0.2$ billion for 1990 to US $\$ 5$ billion for 2002, though it has increased much faster since then reaching US\$7.6 billion for 2003 and US\$13.6 billion for 2004 .

\section{China-India Bilateral Trade}

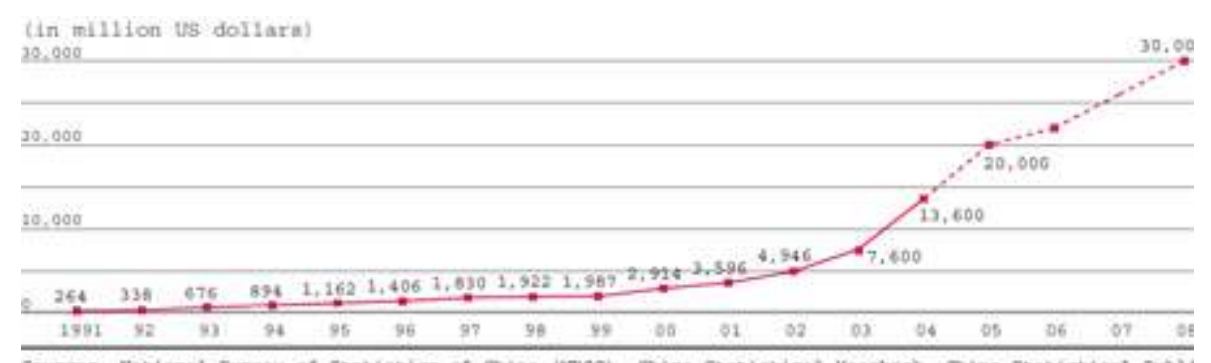

Sourcen: Bational bureau of statiatics of China isesci, China Statistical Yearbook, Oina statistieal Pubil The Ecancate 7 ises, september 19 it 2005 ,

11 Viewed in the context of South Asia, China's trade with India have witnessed impressive increases defying all suspicions about China's special relationship with Pakistan or China's encirclement of India (see Figure 2). To highlight some other strong fundamentals that promise to sustain their current trade boom, while China continues to enjoy a huge favourable balance of trade vis-à-vis most other smaller states of the South Asian region, it is only the China-India trade that has remained to be China's most balanced trade in South Asia and often the balance has been in favour of India. This clearly reflects strong mutual stakes which promise to sustain this trade boom at least in the short term (see Figure 3). Indeed, the two seem to be becoming increasingly relaxed about their bilateral ties and are now thinking of building joint strategies towards their regional and global initiatives. No-one today talks of a China-India clash in South-East Asia where both have built flourishing engagement without any mutual friction or scepticism. While so far they have not allowed this to become a major stumbling block yet their intensifying search for energy sources abroad is lately seen as one area that could post a serious challenge for their economic engagement ${ }^{12}$. 


\section{China's Trade with South Asia}
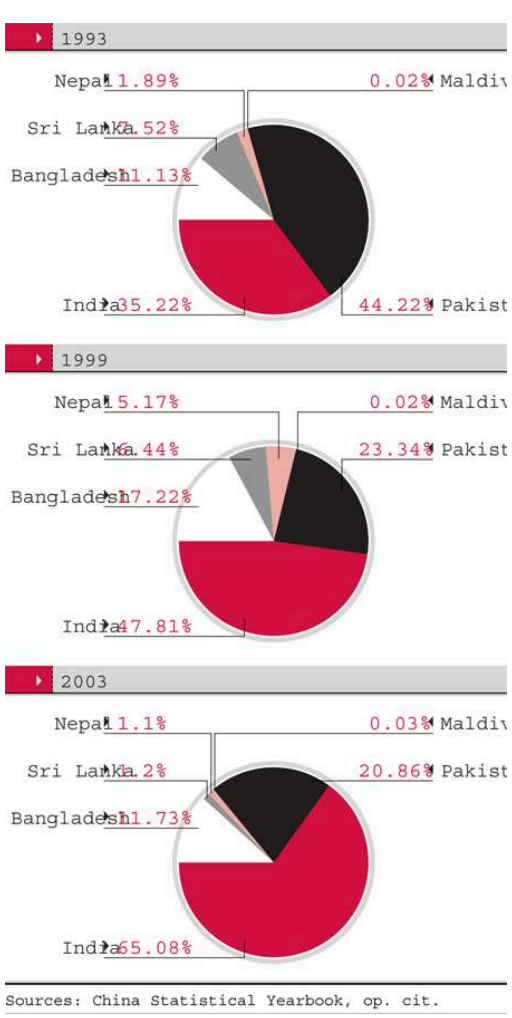

Strong fundamentals of China-India trade

12 It is the nature of China-India bilateral trade as a confidence-building measure that must be underlined to appreciate its interface with their political relations which remains so critical for its long-term prospects. Therefore, more than being measured in terms of statistics and profits, it is the political impact of trade which remains the barometer of their economic engagement. Both sides clearly display that understanding at least in their more recent initiatives. Moreover, with the inclusion of India's trade with Hong Kong and Macao (as also India's rising trade with Taiwan, and the possibility of an eventual unification of Taiwan), Greater China has already emerged as India's largest trading partner and one of its kind.

Major items of export from India to China remain iron and chrome ore, plastic and linoleum, marine products, cotton yarn and fabrics, organic and inorganic chemicals, dye intermediates, bulk drugs and pharmaceuticals, construction quality wire rods, tobacco and tea, while China's exports to India include items like raw silk and silk yarn, coking coal, some types of chemicals, pulses, mercury and antimony, freshwater pearls, pig iron, newsprint and several low-technology consumer items. Gradually, many new sectors-like border trade or high-tech trade-are being also explored while information technology and infrastructure development are already emerging as major areas for co-operation.

Thirdly, it is the dynamism of their economies and societies, especially their young populations and increasingly skilled manpower, that are going to be their critical asset. In absolute terms, as proportion of their total trade or even in terms of per capita trade this may present a dismal picture, yet trends in the growth rate of China-India trade show strong potential and have important political implications. However, even in terms of its share in their total foreign trade, while India accounts for little more than 
$1 \%$ in China's total foreign trade, China now accounts for over $5 \%$ of India's total foreign trade which creates substantial stakes for mutual co-operation ${ }^{13}$.

Finally, their foreign exchange reserves provide perhaps the easiest layman's indicator of their international economic standing. China's foreign exchange reserves, which stood at mere US $\$ 1.6$ billion for 1978, had exceeded US $\$ 659$ billion by March $2005^{14}$. These may not be huge figures compared to those of Japan at US\$843 billion yet they are when compared to India's US $\$ 142$ billion $^{15}$. The same also remains true of their foreign direct investment (FDI) inflows where China and India are often projected as either poles apart or competing against each other. However, both have again continued to sustain growth simultaneously without any major friction. Their FDI remains perhaps the strongest mover of their foreign trade and especially in case of China it has come to be known as the main locomotive for their economic success.

Foreign direct investment

Unlike India, FDI makes China a global player. In 2000, in cumulative terms, China was world's fifth-largest recipient of FDI, after the United States (US\$1.3 trillion), the United Kingdom (US $\$ 497$ billion), Benelux Economic Union states (US $\$ 482$ billion) and Germany (US $\$ 480$ billion). But for 2004, China was to clock the second largest FDI inflow of US $\$ 62$ billion - next only to the United States which makes these FDI inflows the most critical as also most visible indicator of its sustained and rapid economic development ${ }^{16}$. Even India is expected to emerge as the next hot spot for FDI inflows. Amongst others, the UNCTAD-DITE Global Investments Prospects Assessment 2004, estimates for 2004-2007 put China and India at the top two ranks followed by the US as third ${ }^{17}$. This, however, remains rather ambitious, especially for India. Even for China, while it is expected to continue to leapfrog, it is likely to stay at its second position and may not surpass the US for a very long time.

17 But there are indicators that FDI inflows to China (even India) will continue unhindered. For example, China today accounts for over $10 \%$ of US foreign trade destinations and China owns $\$ 167$ billion of US securities issued by the Federal Government ${ }^{18}$. During the year 2000, the total US corporate revenue generated from China was $\$ 7.2$ billion, compared to $\$ 4.6$ billion from Mexico, $\$ 3.5$ billion from Singapore, and $\$ 1.85$ billion from Brazil ${ }^{19}$. Though China faced some phases when FDI had gone down yet it has gradually witnessed rise from $\$ 2.7$ billion for 1984 to $\$ 62$ billion by 2004 , largely staying within the range of $\$ 45$ to $\$ 60$ billion on an average year $^{20}$.

18 By comparison, India's FDI has been generally sluggish and, for the early 1990s India's contracted FDI stood at $\$ 0.15$ billion for 1991 , $\$ 0.23$ billion for 1992, $\$ 0.57$ billion for 1993 , $\$ 0.95$ billion for 1994 , and $\$ 1.96$ billion for $1995^{21}$. But from there, India's FDI has experiences some acceleration and rose to $\$ 3.4$ billon for 2002 and $\$ 4.3$ billion for 2003; and some experts also question calculation methods and suspect underplaying of India's FDI statistics ${ }^{22}$. For year 2004, India's FDI was estimated to exceed a rather impressive US $\$ 8$ billion $^{23}$. And, given this new enthusiasm of the United Progressive Alliance, the government has been talking of absorbing an FDI of US\$15 billion for 2005 and US $\$ 30$ billion for 2007 to reach a total of US $\$ 150$ billion of fresh FDI in next ten years ${ }^{24}$.

19 Among the reasons cited to explain India lagging behind, is the argument that China had decided to open up to FDI back in 1979 and created special economic zones (SEZs) in coastal regions that had the clear advantage of geographical proximity to Hong Kong 
-the hub of capital investment in Asia-, and that China had the added advantage of its political system, cheap labour and special incentives for foreign investors as for its armed forces which were to become major players in China's opening up experiments ${ }^{25}$. Also important is overseas Chinese contributions. Non-resident Indians and overseas Chinese have been distinct categories in FDI inflows into their respective homelands. Beginning only from the early 1990s, while non-resident Indians do contribute a little to India's FDI, overseas Chinese are known to present a unique example by contributing over two-thirds of the whopping inflows of FDI into China ${ }^{26}$.

Institutional arrangements

As regards an evolving overall institutional framework for their bilateral trade, the China-India Joint Working Group for the Boundary Question (JWG) remains the most generic and potent forum for all issues and sets the overall tenor of China-India relations. More specifically, the two also have a JWG for Trade and Commerce which is supported by a Joint Business Council that represents business interests, in particular of the non-state sector. They also have a JWG for Science and Technology that focuses more on research and development sectors. In operative terms, much of the norms and regulations for clearing road-blocks and evolving the new legal framework for trade are facilitated by their regular meetings. Besides, using such opportunities as Summits, many more agreements have been signed between individual Departments and Ministries from both sides ${ }^{27}$.

21 Among some more exciting institutional frameworks, China and India have recently launched discussions to evolve a bilateral free trade area (FTA) agreement. This indicates their desire to go beyond the World Trade Organisation framework and mutually reduce tariffs even further as also to remove non-tariff barriers ${ }^{28}$. Indeed, in their meeting over March 21st-22nd 2004, the senior officials from China and India had launched the first round of discussions for signing a FTA agreement and a comprehensive economic co-operation agreement in Peking. The idea was further followed up during Premier Wen Jiabao's visit to India over April 9th-12th 2005. However, unlike their government, some Chinese experts continue to have strong misgivings. To quote one well-known expert on South Asia, "Although a FTA between China and India will be hard to achieve in the short term, its significance in forming a multi-party regional free trade system is apparent, given the huge population and size of the two countries" ${ }^{29}$. Another Chinese expert believes that the stronger trade ties and complimentary economic structures cannot ensure the quick establishment of a FTA between the two countries" ${ }^{30}$. India has its own reservations and, that cheap Chinese goods are flooding Indian markets has been a source of concern among India's business community as well ${ }^{31}$.

Investments and joint ventures

In international relations, finance capital transfers have been a rather recent phenomenon compared to the trading of goods and services. But mutual investments always reflect greater mutual confidence and provide a great boost to bilateral trade, especially in the long-run. And this is especially true when it comes to China-India bilateral trade. However, as of now, the United States stands out as the largest investor, accounting for about $21 \%$ of India's total FDI inflows. Mauritius follows with a $12 \%$ share, but it is really a conduit for investors from various countries, including the United States, because of a special tax treaty with India which grants exemption from Indian taxes for Mauritius-based companies. The United Kingdom is then the third 
largest investor in India followed by the Republic of Korea, Japan and the non-resident Indians who now account for about $4 \%$ of India's total FDI inflows ${ }^{32}$.

China's export expansion in certain sectors has had a direct impact on similar exports from and investment into labour-abundant India ${ }^{33}$. Yet, there are sectors where China and India have entered into joint ventures and they today hold joint stakes in Kazakh oil firms and Sudan's oilfields. The first China-India joint venture-between India's Mideast Integrated Steel Limited and China Metallurgical Import Export Corporationwas commissioned in Orissa way back in January $1993^{34}$.

As regards India's investments in China, irrespective of its thriving private sector being active since its independence in 1947, the nearest that India's investments were to reach China were Hong Kong. China virtually allowed no foreign investment until the early 1980s. But, even after long years of operations in Hong Kong, few businessman of Indian origin made it really big in Hong Kong's business circles. Also, considering that much of Indian investments remain in services, Hong Kong continued to be the most favoured destination as its obvious attraction as a hub of business and trading. Indeed, it was from here that most Indian business houses made their debut in extending their operations into China mainland.

This, however, is not true of Chinese investment that has been concentrated in India's mining and low-technology manufacturing sectors. However, given their political baggage of their problematic past, Chinese investment into India has not only continued to heavily fluctuate but also continue to suffer from a huge gap between their contracted FDI and their actual absorption in real projects on the ground. For the period between August 1991 and August 2000, while China had contracted an FDI worth US $\$ 225.07$ million with India, the actual inflow was only US $\$ 0.56$ million. Comparing this with their overall performance in attracting FDI, both India and China have separately faired much better, which shows that the pace of their mutual investments still continues to be guided by their bilateral politico-strategic equations.

The reality, however, has been changing rapidly in last few years. India's Ranabaxy pharmaceuticals and National Institute for Information Technology (NIIT), today clearly dominates China's pharmaceuticals and IT education. There have also been several other smaller and less known initiatives in IT education. India's Tata Group, one of largest conglomerates in Asia, plans to increase its investment from US $\$ 2$ million to US $\$ 5$ million in China's software sector and has also been in discussion about jointventure projects in other sectors like automobiles and steel ${ }^{35}$. China's home electrical appliance makers Guangdong province-based Konka and India's Tata Consultancy Limited (TCL) have also established joint ventures in India. China's Konka though halted its manufacturing in India due to the allegedly restrictive policies and it was reported to have deep difference with its Indian partners ${ }^{36}$. But again, during the June 2003 visit by Prime Minister Vajpayee, China had pledged to invest US $\$ 500$ million in India's infrastructure sector ${ }^{37}$.

Impact of nuclear tests

27 Without doubt, India's nuclear tests of 1998 had presented the most serious acid-test for China-India trade relations. There are various ways to examine how China-India trade and commerce were affected by these tests, and how bilateral trade proved to be a major catalyst in facilitating the post-1998 official and political interactions. Prime facie, their bilateral trade had suffered a visible setback the growth rate tumbling from an average $78 \%$ during the preceding eight years to mere a 3.4\% for 1998. More curious 
was the follow-up: China-India trade was to undergo an exponential boom these last seven years following the 1998 nuclear test (as shown in Figure 1). Indeed, a month-tomonth change in China-India trade for 1998 presents a most startling picture of the business sector as the first to bounce back in a matter of six months, between May and November 1998.

Trends in trade surplus can be another important indicator of the impact of nuclear tests on bilateral trade ties. Beginning from the early 1990s, while India had enjoyed a trade surplus during 1992, 1993 and 1996, the trade surplus was with China during 1994, 1995, 1997. In fact, according to experts, the China-India trade was known to experience fluctuations even within each year as India generally enjoyed a trade surplus during the first half of the year while in China this trend was reversed during the last few months, every time. For 1997, for example, during the first eight months of 1997 , there was a trade surplus in favour of India of US $\$ 40$ million. Very suddenly, China's exports experienced faster growth resulting in China having a trade surplus of US $\$ 53$ million by November which dropped to US $\$ 36$ million by the end of December ${ }^{38}$. But no such trend was seen during 1998 when the trade surplus with China reached its peak of US\$110 million though this rectified itself in 1999.

All that we had were the symbolic cancellation of China Commodity Fair in Mumbai during August-September 1998 and China's visibly low-profile presence during New Delhi's India International Trade Fair during November 1998. This did create scepticism among businessmen on both sides. Academic exchanges were the second important sector to return to normal, not letting political polemics overshadow positive economic initiatives. In addition, when seen in the larger context of China's negative growth rates in their annual trade with Asia, even the low positive growth in Sino-Indian bilateral trade for 1998 trade inks was seen to bode very well for Sino-Indian ties ${ }^{39}$.

Economic versus strategic priorities

30 How much China-India bilateral trade has been unaffected by politics? Have these evolved any separation from their politico-strategic scepticism or do the two remain fatally intertwined? China-India interaction following India's nuclear tests in May 1998 again provides an ideal case for such analysis. Very briefly, it was only during the period of strong political polemics of the initial period of India's nuclear tests that saw some economic interaction being cancelled or postponed and Indian exports suffering a visible setback during the first three or four months.

31 Indeed, the growth rate of China-India trade had already started slowing down from an average of $78 \%$ for the first eight years of the 1990 s, by about $30 \%$ per year during the mid-1990s. It had further slid to 5.2\% for 1997. Seen against the backdrop of the East Asian financial crisis of late 1990s, China's exports had also witnessed a general decline. China's exports to its major trade partners like Japan and South Korea as also its closest ally Pakistan, sent a very positive message to India's policy-makers. Even during those difficult months of the summer of 1998, India signed agreements for five joint ventures (two in China and three in Hong Kong) during 1998 involving an investment of US\$8 million and other six joint ventures (one in China and five in Hong Kong) during 1999 involving investment of US $\$ 1.9$ million $^{40}$.

China's overall exports which were expected to grow at a respectable 9\% (from its heady $20 \%$ growth during 1997) grew only by $0.5 \%$ for 1998 and imports actually fell by $-1.5 \%$. China's exports to even its more stable Asian partners had plunged sharply-South Korea by $31.3 \%$, Hong Kong by $11.5 \%$ and Japan by $6.7 \%$. Against this 
scenario, Chinese exports to India grew by a respectable $8.9 \%$. In 1998-the year of India's nuclear tests-India's share of China's international trade actually increased to $0.59 \%$ from $0.56 \%$ for $1997^{41}$. It has since risen to $0.9 \%$ of China's overall foreign trade for 2003 and to $1.1 \%$ for 2004. India's nuclear tests and other political rhetoric have had only a limited impact on China-India bilateral trade. Their trade relations have had a much stronger positive impact and facilitated their political turnaround which has potential for strong fundamentals for their trade relations.

Although India's software is becoming famous and is attracting attention in most debate on China-India trade, given the labour-intensive nature their economies, both will have to be exceptionally innovative to sustain the current boom in their trade relations. No doubt, the two have so far handled their economic engagement deftly enough but their rise to capture global resources and markets is very likely to increasingly complicate their equations. For instance, in view of their rapidly rising demand for energy, recent months have seen China and India beginning to undercut each other in seeking control and stakes in various oilfields and oil firms ${ }^{42}$. Strands of possible economic competition do exist, and the chances of their bilateral trade emerging as a stimulant for an eventual political stand-off cannot be completely ruled out. This means that this second phase of their bonhomie remains as yet pretty fragile.

To be sure, China today aspires to match India's success as an exporter of software and Taiwan's as an exporter of hardware. If India has the advantage of language, China produces three times the number of engineers as India, and Chinese companies like Legend are proving serious competition to other brands and occupy $26 \%$ of China's market. China's nascent private sector has already emerged as the most promising and potent driving force in China's economic opening-up exercise. During 1989-1997, China's private enterprises grew in number from 90,581 to 960,726 firms, which amounts to an annual increase of $34.3 \%$. The workforce has increased from 1.64 million to 13.49 million, an annual increase of $30.1 \%$ and their capital has increased from 8.4 billion yuan to 514 billion yuan, an increase of $67.2 \%{ }^{43}$. None of these can be ignored as paper tigers and will provide both several new challenges and opportunities for ChinaIndia trade relations.

The return of Hong Kong to China has strengthened the China link of India's business community, many of whom have lived and thrived in Hong Kong for over one hundred years. Juxtaposed with China's emerging private enterprises, these new trends have provided new momentum for China-India trade relations. It is especially this economic engagement between their non-state sectors that has now begun to provide steam to the China-India political rapprochement, promising to gradually emerge as an important force in moulding the nature and magnitude of China-India trade relations. Nevertheless, given the multifaceted challenges for their economic engagement, the hope lies in the two being able to continuously innovative to strengthen and evolve their bilateral trade on the basis of mutual understanding and mutual confidence. 


\section{NOTES}

1. "India: the world's $4^{\text {th }}$ largest economy: World Bank", The Indian Express (New Delhi), June 16th 2004, p. 7. Citing the World Bank's annual report Word Development Indicators 2004, it shows that the largest five states in terms of purchasing power parity stood at US $\$ 10,414$ billon followed by China at US $\$ 5,792$ billion and then Japan at US $\$ 3,481$, India at US $\$ 2,778$ billion and finally Germany at US $\$ 2,226$ billion.

2. For details see Swaran Singh, China-India Economic Engagement: Building Mutual Confidence, New Delhi, Centre de Sciences Humaines, March 2005, pp. 17-20.

3. China and India have had a long-standing boundary dispute which involves territories of over 138,000 sq kms on which they had fought a short but violent war in 1962 which had been followed by their continued scepticism about each other. The presence of HH Dalai Lama and 100,000 Tibetans in India and China's special relations with Pakistan has been two other issues of mutual concern. It was only from the early 1970s that the two sides began to revive their close relations but progress has been slow with several hiccups.

4. China-India trade began to return to normal in July 1998. Culture and commerce has linked these two ancient civilisations since the second century BC. For details see Swaran Singh, China-South Asia: Issues, Equations, Policies, New Delhi, Lancers Books, 2003. 5. Swaran Singh, "China-India Border Trade: A Tool for Building Mutual Confidence", in Isabelle Saine-Mezard and James K. Chin (eds.), China and India: Political and Strategic Perspectives, Hong Kong, Centre of Asian Studies, 2005, pp. 67-68.

6. "Indo-China Trade Relations", Indian Economy Overview (Internet Edition) at http:// www.economywatch.com/world_economy/china/indo-china-trade-relations.html.

7. As Finance Minister to Prime Minister P.V. Narasimharao, he was the mastermind in that government's New Economic Policy during the early 1990s. He has also been a long-standing advocate of lowering of trade barriers and, decades earlier, had written his Ph.D thesis at the University of Cambridge on the subject of the benefit of international trade to India.

8. Zou Huilin, "Foreign workers flocking to Shanghai" in China Daily, Peking, May 14th 2004, p. 1.

9. M. K. Venu, "India, China may join hands at WTO ministerial", The Economic Times (New Delhi), September $19^{\text {th }} 2005$.

10. M. K. Venu, "Strategic cooperation defines our ties", [interview with Chinese Ambassador Sun Yuxi], The Economic Times (New Delhi), September 22nd 2005, p. 10. 11. Key Indicators 2003: Education for Global Participation, Manila, Asian Development Bank, 2003), p. 160; also "China seeks free trade zone with Japan, South Korea", Asia News (Online Edition) May $5^{\text {th }}$ 2005, at http://www.asianews.it/view.php? $\mathrm{l}=\mathrm{en} \& \mathrm{art}=3210$.

12. Amitav Ranjan, "Let's shop for oil, gas together: India, China", The Indian Express, New Delhi, August 24 $4^{\text {th }} 2005$, p. 14; Indrani Bagchi, "Energy deals: India, China at loggerheads", The Times of India (New Delhi), August 27 $7^{\text {th }}$ 2005, p. 12; "Dragon-Elephant tango in oil market", The Economic Times (New Delhi), October $14^{\text {th }} 2005$, p. 4.

13. "Likely Sino-Indian FTA Conducive to Nation", China Business Weekly, Peking, April 12th 2004, p. 1. 
14. China's foreign exchange reserves, 1977-2005, State Administration of Foreign Exchange, People's Republic of China (Online Edition), http://www.chinability.com/Reserves.htm. 15. "Japan April forex reserves rise 5.88 billion" Mabico Financial Company, at http:// www.mabico.com/en/news/20050511/foreign_exchange/article22487; "India's foreign currency reserves rise to US\$142 Billion", at http://isyourjobgoingoffshore.com/ forums/showthread.php?t=761; For details on this and other related issues see http:// www.economist.com/research/ArtifclesBySubject/displayStory.cfm? story_ID=24643388subjectid=348879.

16. There is an interesting book by Yasheng Huang, Selling China: Foreign Direct Investment During the Reform Era, New York, Cambridge University Press, 2003. This argument clearly contradicts the conventional wisdom. For 2004 statistics see "UN: China's FDI Benefits Neighbours", at China Radio International English website at http:// en.chinabroadcast.cn/532/2005-3-8/116@214189.htm.

17. Guo Huaigang, "China's Foreign Direct Investment Strategy”, Business Beijing, (Online Edition), October 2004, available at http://www.btmbeijing.com/contents/en/ business/2004-10/investment/investment.

18. Amit Mitra, "Let's Talk Business: Economics as the Cornerstone of Diplomacy", The Times of India (New Delhi), May $2^{\text {nd }} 2005$, p. 16.

19. David Hale and Lyric Hughes Hale, "China Takes Off", Foreign Affairs (New York), Vol. 82 No. 6, November-December 2003, pp. 38-42.

20. Jun Ma, The Chinese Economy in the 1990s, London, Macmillan, 2000, p. 121.

21. Charles R. Chittle and Kyoo H. Kim, "Foreign direct investment in China and India: The economic environment", in Sam Dzever and Jacques Jaussaud (eds.), China and India Economic Performance and Business Strategies of Firms in the Mid-1990s, London, Macmillan Press, 1999, p. 6.

22. Chandana Chakroborty and Parantap Basu, "Foreign direct investment and growth in India: a co-integration approach", Applied Economic, Vol. 34, No. 9, June 15th 2002, p. 1062; also Suma Athreye and Sandeep Kapur, "Private Foreign Investment in India: Pain or Panacea?", The World Economy, Vol. 24, issue 3, March 2001, p. 402; Nirupam Bajpai and Nandita Dasgupta, "What Constitute Foreign Direct Investment? Comparison of India and China", CGSD Working Paper No. 1 (Online Edition), January 2004, available at http://www.earthinstitute.columbia.edu/cgsd/documents/ bajpai_fdi_india_china_002.pdf, p. 2; . "India is among top four FDI destinations", The Hindu (New Delhi), September $23^{\text {rd }}$ 2004, p. 18.

23. According to the UNTAD annual report titled The World Investments 2004, India has clocked an FDI of US $\$ 4.3$ billion for 2003, which is a $25 \%$ increase over the preceding year which makes the target for 2004 credible.

24. "Government plans mainframe to attract US $\$ 150 \mathrm{bn}$ infrastructure investment", The Economic Times, New Delhi, October 20th 2004, p. 1; also "Government keen to attract \$150bn FDI", (Business), October 19th 2004 available at http://inhome.rediff.com/ money/2004/oct/19fdi.htm.

25. Charles R. Chittle and Kyoo H. Kim, op.cit., p. 7; also M. R. Narayana, "Foreign Direct Investment and Inter-regional Growth in China: Lessons for India", China Report, Delhi, Vol. 40 No. 1, January-March 2004, p. 2.

26. Charles R. Chittle and Kyoo H. Kim, op.cit., p. 20.

27. For detailed chronological list on China-India agreements see Ministry of Foreign Affairs, People's Republic of China, http://www.fmprc.gov.cn. 
28. M. Saqib and D. Chakraborty, India China Free Trade: Examining the Likely Impact of the FTA, New Delhi, ICTC Monograph Series Paper 1, 2005, p. 44.

29. "Likely Sino-Indian FTA Conducive to Nation", China Business Weekly, Peking, April 12th 2004, p. 1.

30. Ibid.

31. Rahul Bajaj (Chairman, Bajaj Auto), "Flot Trade Agreements: Exports Need Policy Impetus, Not Low Tariffs", The Times of India, New Delhi, April 28th 2005, p. 16; also see B.M. Jain, "India-China Relations: Issues, Trends and Emerging Scenarios", China-India Project Occasional Paper No. 1, Hong Kong, Center for Asian Studies, 2003, (Online Edition) available at http://www.hku.hk/cas/pub/Occasional1_bmjain.pdf; and B.M. Jain, "India-China relations: issues and emerging trends", The Round Table, UK, Kent, Vol. 374, April 2004, p. 259.

32. Pradeep Agarwal, "Economic Impact of Foreign Direct Investment in South Asia", in Aditya Mattoo and Robert M. Stern (eds.), India and WTO, Washington DC, The International Bank for Reconstruction and Development, 2003, pp. 121-122.

33. Ross Garnaut and Yiping Huang, "China and the future of the international trading system”, in Peter Drysdale and Ligang Song (eds.), China's Entry to the WTO: Strategic Issues and Quantitative Assessments, London, Routledge, 2000, p. 15.

34. "Beijing establishes joint venture in India", Xinhua, cited in Foreign Broadcast Information Service-China-93-013, January 22 ${ }^{\text {nd }} 1993$, p. 15.

35. Some of the well known Indian companies include Tata Exports (Shanghai), NITT (Shanghai), Bry Air (Shanghai), Essel Packaging (Guangzhou), Ranbaxy (Guangzhou and Shanghai), Ofind Refractories (Liaoning), Wockhardt (Peking), Lupin Laboratories (Guangzhou), August International (Peking), Archean Granites (Peking), Ispat Karmet (Urumqi), State Bank of Indian (Shanghai).

36. See note 23.

37. “China pledges $\$ 500 \mathrm{mn}$ investment in India”, June 23rd 2003 available at http:// sify.com/finance/fullstory.php?id=131791488vsv-157.

38. A Status Report on China-India Trade \& Investment 1998, Shanghai, Confederation of Indian Industries, November 1998, p. 4.

39. "Statistical Communique of the People's Republic of China on the 1998 National Economic and Social Development", (Document), Beijing Review, Peking, Vol. 42 No. 13, March 29th-April 4th, 1999, pp. 35-50.

40. Indian Joint Ventures and Wholly Owned Subsidiaries Abroad Approved During 1999, New Delhi, Indian Investment Center, pp. 8 and 32; and Indian Joint Ventures and Wholly Owned Subsidiaries Abroad Approved During 1998, New Delhi, Indian Investment Center, p. 6, p.

28.

41. For details see "China's Economy and China-India Trade", Journal of The SICCI (Southern India Chambers of Commerce and Industry, Chennai, India), July 1999, pp.

12-14; also see FIEO News (Online Edition) at http://www.fico.com, August $1^{\text {st }} 1999$, p. 21.

42. Jason Bush, "A rage for oil", The Economic Times, New Delhi, September $18^{\text {th }} 2005$, p.

17.

43. "Private Sector Grows Fastest of All", Beijing Review, Peking, Vol. 42, Nos. 10-14, March 9th-10th 1999, p. 4. 


\section{RÉSUMÉS}

Booming bilateral trade has come to be the strongest pillar of China-India rapprochement. This has not only since overtaken the pace of political confidence-building but also has a substantial impact on their mutual perceptions. Their border trade has especially brought about a noticeable transformation in their remote and problematic border regions. This has contributed to overall tranquillity and peace in the area and has as well facilitated progress in their border negotiations.

This boom in trade has also introduced new trends. The two states are no longer only recipients on foreign direct investment but have entered into a new phase of being investors, both mutually as in other regions. In this new context, the increasing deficit in the energy sector and the competition to capture new markets present major challenges to sustaining this boom in their bilateral trade. 